\title{
KULTUURIMÄLU TRANSMEEDIALISUS
}

\section{Rand Teise maailmasõja paadipõgenemisi vahendavates kunstitekstides}

\author{
MAARJA OJAMAA
}

\section{Sissejuhatus}

$\mathrm{K}$

unstitekstid $^{1}$ on oluliseks allikaks, mille põhjal kujuneb kultuurikandjate arusaam ajaloost. Nende toime sündmuste modelleerimisele kultuurimälus pole sugugi vähemtähtis ajalooteaduslike, pedagoogiliste või memuaarsete tekstide omast. Üht ja sama episoodi vahendavad teosed ei asetse kultuurimälus mitte eraldiseisvatena, vaid sulanduvad kokku uue tasandi tervikuks. Nii on õigustatud ka suure ajalise distantsiga või muude tunnuste poolest erinevate käsitluste koos vaatlemine. Artiklis uuritavaks materjaliks on kolmes erinevas meediumis eri aegadel loodud kunstitekstid, mille keskmes on üle mere põgenemised Teise maailmasõja ja Nõukogude okupatsiooni eest. Põhiküsimuseks on seejuures, kuidas mõjutavad ajaloosündmuse kujutamist erinevate meediumide väljendusvahendid, mis on loomulikult tihedalt seotud ka küsimustega autori stiilist, sotsiokultuurilisest kontekstist jm.

Transmeedialisuse mõiste tuum on lähedane arusaamale kultuuri - ja õigupoolest igasuguse semiootilise süsteemi - vältimatust mitmekeelsusest (Lotman 1999: 43). Meedia ja keele mõistet kasutatakse allpool sünonüümidena kommunikatiivse märgisüsteemi tähenduses (Lotman 2004: 8). Eesliide trans- artikli keskses mõistes viitab aga kultuurikeeltevahelistele ülekandesuhetele kõige laiemas mõttes (Lotman 2001a: 15). Eri keelte vahelised tekstide ja tähenduste ülekanded ja seeläbi nende variatiivne kordamine on üks olulisemaid sidusust loovaid mehhanisme kultuuris.

Peeter Toropi (2008: 725) määratluses on transmeedialisus kultuuri fundamentaalne tunnus, ehk: „tekstide kultuuris eksisteerimise mentaal[ne] aspekt”. Transmeedialisuse uuringute keskseks küsimuseks on narratiivi (või teksti) ja selle meediumi suhted (Herman 2004: 49) ja meetodiks mingisuguse invariantse elemendi võrdlev analüüs eri meediumide tekstides. Sellise analüüsi eesmärgiks on muuta nähtavaks invariantse elemendi variatiivne ehk meediumipärane kordumine. See aitab mõista ühelt poolt loo enese tuuma ja teisalt meediumide narratiivseid omadusi ja võimalusi.

Lähemalt käsitleb siinne artikkel August Gailiti romaani „Üle rahutu vee” (1951), Sulev Keeduse filmi „Somnambuul” (2003) ning Eerik Haameri õlimaali „Perekond vees” (1941, EKM M 1716). Nimetatud ei moodusta kaugeltki kõiki üle mere põgenemise teemaga seotud kunstilisi allikaid, vaid valiku, mida motiveerivad artikli maht ja tekstide asend kultuurimälus. Eesti ran-

${ }^{1}$ Teksti mõistet kasutatakse artiklis kultuurisemiootika traditsioonile omasel avaral moel, mõistes selle all igasugust terviklikku tähendust ja funktsiooni kandvat struktuuri. Kunstiteksti all mõistetakse ükskõik millise kunstiliigi väljendusvahenditega loodud teksti. 
dadelt Rootsi, Soome ja Saksamaale lahkumise haripunktiks oli 1944. aasta septembrikuu lõpp. Meritsi põgenenute täpne arv on teadmata, kuid kokku lahkus Teise maailmasõja ajal Eestist vahemikus 75 000-80 000 inimest (Kumer-Haukanõmm 2011: 95). Kirjanik Gailit nagu paljud tema kolleegid ${ }^{2}$ läks Tallinnast laevaga 20. septembril, kuid „Üle rahutu vee” paadipõgenike loo otseseks aluseks on põgenemiskogemust kirjeldav kiri kaasmaalaselt (Kasterpalu 2009: 244-253). Eerik Haameri ${ }^{3}$ 48-tunnine teekond Rootsi algas ööl vastu 19. septembrit Vilsandi piirivalve päästepaadiga (Kõiv 2008: 114-115). Sulev Keedus sündis alles 13 aastat hiljem, kuid isiklikult mäletab 1944. aastat kui Eesti saatuse pöördehetke „Somnambuuli” kaasstsenarist Madis Kõiv.

Episoodromaan „Üle rahutu vee” on olulisemaid eestlaste põgenemisteekonna kirjanduslikke esitusi. Teised paguluses ilmunud ilukirjandusallikad ${ }^{4}$ käsitlevad seda traumaatilist teed pigem lühidalt, keskendudes enam kohanemisele uuel maal. Teemat on käsitlenud aga ka Nõukogude Eestis ilmunud kirjandus, nende seas eesti draamakirjanduse tüvitekste, Jaan Kruusvalli näidend „Pilvede värvid”, mis on eestlaste kultuurimälus suureks saanud eelkõige Mikk Mikiveri vormilt lihtsa, askeetlikugi, ent mõjusa Draamateatri lavastuse (1983) kaudu. Romaanidest on üks tuntumaid Herman Sergo „Põgenike laev” (1966), kaheosaline suguvõsalugu purjekas „Pääsukese” korrastamisest, mis viib end eksiteele juhtida lasknud tegelased hukatusse.

„Üle rahutu vee” esmatrükk ilmus aastal 1951, ehkki käsikiri valmis juba 1947. Toona jäi teos praktiliselt avaliku tähelepanuta hoolimata Henrik Visnapuu üleskutsest (1951: 7): „[o]leks väärt avaliku diskussiooni korras selle raamatu üle mõtteid vahetada ja Gailiti tegelaste teeside kohta seisukohta võtta." Vaikuse üsna ilmseks põhjuseks oli autori ehmatav hoiak pagulaste suhtes, keda ta kujutas vähimagi heroiseeriva varjundita juurtetute põgenejate, mitte vabaduse alalhoidjatena. ${ }^{5}$ Ometi luges Visnapuu Gailiti teosest välja ka lunastuse lootuse. Iseseisvuse taastanud Eestis on tänaseks ilmunud kaks romaani kordustrükki ja mõlemat saatsid ka järelsõnad (Matjus 1998; Kasterpalu 2009). ${ }^{6}$

2003. aastal esilinastunud „Somnambuulil” on kahtlemata rohkem vaatamisviise kui üksnes ajaloofilm, seda hoolimata raamist, mis on alguses määratlusega „Sügis 1944” ning lõpus ajalooliste andmete kirjega selgelt markeeritud. Kui Gailiti romaan keskendub põgenikele, siis Keeduse filmi fookuses on rannale mahajäänud. Teoste oluline sarnasus on aga tegelaste üldistumine kogu rahvaks. Ehkki Keeduse Gottfriedi, Eetlat ja Kasperit võiks nimede järgi pidada rannarootslasteks, saab nende lugu tõlgendada kogu selle maa rahva, eestimaalaste lämmatamise loona.

${ }^{2}$ Piret Kruuspere (2008: 9) hinnangul lahkus toonastest Kirjanikkude Liidu liikmetest umbes kolmandik, kusjuures mitmed kirjanikud jäid sama plaaniga hiljaks ning olid sunnitud kodumaale jääma. Gailitiga ühes laevas lahkusid näiteks ka Marie Under ja Artur Adson (vt Adson 1994).

${ }^{3}$ Kaalu Kirme (2007: 266-267) andmetel suundus eksiili 106 kunstnikku ehk üle poole kõigist toona tegutsenud professionaalsetest kunstnikest.

${ }^{4}$ Nt Pedro Krusteni „Üle parda” (1946), August Mälgu „Öised linnud” (1945) ja „Kodumaata" (1947) jt.

${ }^{5}$ Väheste tagasiside andjate seas oli ka Karl Ristikivi (1951: 6), kes nii Gailiti stiili kui ka süžeesse omajagu üleoleva kriitikaga suhtus ning teost reaalsuse põhja kaotanud ideoloogiliseks ülepingutuseks nimetas.

${ }^{6}$ Nüüdseks eksisteerib teos siinses kultuuriruumis juba iseenesest transmeedialisena: Margus Kasterpalu dramatiseeris romaani ühes Gailiti „Isade maaga” (1935) ning tõi selle 
Keedusele on stsenaristi ja režissöörina omane süvenev, ümbertegemisi ja kustutamisi salliv ja sestap pikaldane töö. „Somnambuuli” esimene stsenaariumivariant jäi üles filmimata, ent sellest sai Keeduse mitmekordse kaasstsenaristi Madis Kõivu kuuldemäng „Üks teine lugu” (2003), mis kujutab samas aegruumis traagilise lõpuga suhtekolmnurka. „Somnambuuli” peategelane Eetla tuleb tagasi viimaselt põgenikepaadilt ja jääb ühes majakavahist isaga ainsate põliselanikena tühja rannakülla. Edasine käivitub armeest deserteerunud arsti Kasperi ja vene sõdurite - nende seas tumma Ivanese - saabumisega. Film on üles ehitatud lühilugude triloogiana, peegeldades sündmusi sügisel, talvel ja kevadel 1944-1945, mille jooksul Eetla meeleseisund, haigus või hullumine, une ja reaalsuse piiril võnkumine, üha süveneb. Temas võitlevad paaniline hirm vägistamise ees ning teisalt selle sõge provotseerimine.

Eerik Haameri õlimaal „Perekond vees” (1941) valmis mitu aastat enne põgenemistelainet, kuid on meie kultuurimälus paljuski selle meeleheitliku episoodiga tugevalt seotuks saanud. Maali on üsna palju reprodutseeritud (vt Onoper 2008: 26) ja erinevates kontekstides eksponeeritud ${ }^{7}$ ning selle püsivat kõnekust väljendab muuhulgas teose Kumu-poolne läkitamine Eesti esindajana 2007. aastal Rooma lepingu 50. aastapäevale pühendatud kunstinäitusele Euroopa loost.

\section{Mitmekeelne kordamine ja kultuuri autokommunikatsioon}

Järgnev alapeatükk avab pisut transmeedialise motiivianalüüsi kultuurisemiootilist konteksti, selgitades lähenemise seoseid kultuuri, keele ja teksti mõistetega. Lähtekohaks on siin arusaam, et sidus kultuur on mäletav kultuur. Kultuuri tervikuna võibki mõtestada ka indiviidiülese mälumehhanismina (vt Lotman 1985) ning kõiki selles aset leidvaid kommunikatiivseid ja metakommunikatiivseid protsesse kultuuri autokommunikatsioonina (vt Lotman 2001b: 20-35). Kultuurimälu keskmeks ei ole üksnes säilitav funktsioon, vaid samavõrra oluline on selle toime uute keelte, tekstide ja tähenduste loomisel.

Selleks et mõne sündmuse või isiku lugu tähendusliku ja kõnetavana aktiivses kultuurimälus püsiks, tuleb seda korrata. Mida erinevamates keeltes seda tehakse, seda rikkam on mälupilt. Peagi pärast Rootsi põgenemist avaldas Boråsi Eesti Seltsi juures tegutsev eestlust jäädvustav toimkond raamatu „Eesti põgenikud Rootsis sõnas ja pildis, 1944-1946” (Moor jt 1945). See pidi eelkõige toimima enesekirjeldusena, lõimides põgenikke ja hoides nende rahvusteadvust. Põgenemisteekonnale on raamatus pühendatud eraldi peatükk, milles rõhutatakse mineku raskust, otsitakse sellele õigustust ning samas avaldatakse lootust:

Võibolla tuleb aeg, mil näeme suurfilmi, kus tuhanded - mehed, naised

ja lapsed - jätavad maha oma kodud ja talud ning võitlevad pisipaatidel

2012. aasta kevadel Rakvere Teatri lavale. Samuti oli Kasterpalu stsenaristiks romaaniga samanimelisele Peeter Brambati telefilmile (1996), mis vahendab Rootsi põgenenute mälestusi ja on eksplitsiitselt seotud nii Gailiti teose kui ka tema isiklike kirjadega.

${ }^{7}$ Viimane isikunäitus „Eerik Haamer - kahel pool merd” oli 2008. aastal üleval Kumus. Samuti kaasati maal näiteks Eesti Vabariigi 90. juubeli vastuvõtu näitusele 1941. aasta esindusteosena. 
läbi Balti mere sügistormide lääne poole. Võibolla siis seletatakse ka, mispärast need tuhanded põgenesid ja eluga riskisid.

(Arro 1945: 12)

Ehkki kirjanduselu jätkus võimaluste piires täie hooga ja muuhulgas kirjutati ka põgenemisest, nähti siiski vajadust vahendada sündmust ka filmikeeles kui teistsuguse sotsiokultuurilise positsiooniga märgisüsteemis.

Kultuuridünaamika tingimuseks on niisiis asümmeetriliste (vastastikku ekvivalentseid elemente sisaldavate, kuid tervikuna tõlkimatute) kultuurikeelte kooseksisteerimine. Samas on kultuurile omane ka vastassuunaline tendents ehk püüd mitmekesisust lõimida, sidusa terviklikkuse poole liikuda. Sellist toimet loovad süsteemi omadus sisaldada vastandliku süsteemi elemente $^{8}$ ning tekstide kõrvutamine ja kõrgemal struktuursel tasandil ühtseks tervikuks ühendamine. Ilmekad on siin näited ekraniseeringutest, kus kirjandusteksti ja selle filmikeelse tõlgenduse vahel ei olegi kultuurimälus enam võimalik selgeid piire tõmmata. Näiteks võib küsida, millistes piirides on „Kevade" eestlaste kultuurimälus pärit Oskar Lutsu romaanist, millistes Arvo Kruusemendi filmist. Kõne all ei ole üksnes filmi poolt lisatud pildilised ja helilised aspektid, nagu tegelaste välimus või filmi tunnusmeloodia Veljo Tormise süidist, vaid ka sõnalised, kuivõrd mitmed Lutsu kirja pandud väljendid on laiemasse kasutusse jõudnud just pärast filmis kõlamist. Samal põhimõttel kõrvutuvad ja sulanduvad eri meediumides antud paadipõgenemistekstide rannamotiivid: rand ei ole üksnes sisemaa ja avamere vaheline visuaalne piirjoon, vaid hakkab kaasama ka sõnalisi, helilisi jt modaalsusi.

Kultuurisemiootika teeside autorid viitavad, et üks ja sama teade „võib erinevatel tasanditel esineda teksti, teksti osa või tekstide kogumina" (Uspenski jt 1998: 66). Nii on ka ajalooromaan ühtaegu terviklik tekst, tekstiosade (millest mõni võib olla eelnevalt iseseisva tekstina avaldatud kirjandusajakirjas) kogum, aga ka osa näiteks sama ajaloosündmust või perioodi käsitlevate tekstide kooslusest. Erinevaid kooslusi võivad moodustada konstruktsioonid, nagu pagulaskirjandus, aga ka üht ajaloolist sündmust vahendavad kunstilised ja mittekunstilised allikad. Kõikidele nendele tasanditele on omane teatav struktuurne samakujulisus, need kõik on omakorda analüüsitavad tekstina.

Operatsionaalse mõistena on tekst niisiis kohaldatav ka ajaloosündmuse analüüsimiseks ühelt poolt piiritletud terviku ja teisalt dünaamilise mälumuutujana. Dünaamika väljendub siin asjaolus, et varasemad esitused suunavad hilisemate tõlgendamist ja hilisemad omakorda varasemate ülelugemist. „Varasem” ja „hilisem” on siin muidugi suhtelised mõisted, kuivõrd hilisemaid tekste võidakse sageli ka varasematena mäletada, mõned versioonid võivad aga pikemaks või lühemaks perioodiks ununeda. On küllalt palju noori eestlasi, kelle jaoks „Nimed marmortahvlil” on ennekõike film, seejuures hollywoodiliku sõjafilmi esteetikas loodud film.

Kõikide ühtsama ajaloosündmust esitavate tekstide pinnalt tekkiv terviktekst säilib kultuuris invariandina, mis aktualiseerub läbi variatiivsete esituste, säilitades seejuures oma identiteedi. Selles mõttes avaneb iga uus esitus, näiteks ekraniseering, kultuuri autokommunikatsiooni raamistikus kui teksti ülelugemine ning iga sellise ülelugemisega aktualiseerub ühtlasi varem varja-

${ }^{8}$ Lihtsamateks näideteks on värvisõnad kirjandustekstides, mängud sõnaliste metafooridega visuaalsetes kunstides jne. 
tud, kuid tekstis immanentselt sisalduv tähendusliku dünaamika reservuaar. Viimane avaneb kokkupuudetes uute sotsiaalsete ja kunstiliste kontekstidega. Teksti tähendus seega mitte ei säili, vaid kasvab (vt Lotman 1985). Erinevate ülelugemiste pinnalt tekib mentaalne tervik nii individuaalses mälus kui ka indiviidiüleses kultuurimälus.

Reaalses kultuuriruumis ja kultuuriprotsessides on ühe sündmuse erikeelsed esitused üksteise olemasolu tingimuseks ning segunevad väga mitmekesistel viisidel ja eri tasanditel. See on ka põhjus, miks ajalooromaan on kultuurimälu meediumina mitte üksnes lahutamatu teistest ajalugu vahendavatest kunstiliikidest, vaid osa sama kultuuri ajaloofilmist, ajalooainelisest maalikunstist ja vastupidi.

\section{Ranna variatsioonid}

Artikli analüüsiosas otsustasin fokuseerituse huvides keskenduda ranna kujundile, mis on üks korduvaid motiive kõigis 1944. aasta põgenemise mäletamist modelleerivates tekstides, seda hoolimata tõdemusest, et esmalugemisel ei paista rand neis toimivat keskse kujundina. Ruumikujundit aga põhjendab esmalt põgenemise ruumiline iseloom. Laiemas plaanis on näiteks Maie Kalda (2000: 327-328) näinud just ruumikujundeis Eesti kaheks jagunenud rahvuskirjanduse võrdlemiseks viljakat alust. Kitsamalt põgenemisteemalise pagulasproosa puhul on Tiina Kirss (2002: 1872) võtmekujundina välja toonud pigem pildi „paadist tormisel merel”.

Vahetult pärast Teise maailmasõja aegseid põgenemisi muutis nõukogude kord Eesti rannad avaruse ja dialoogi aegruumist eraldajaks ja katkestajaks. Sellega ei kistud lõhki üksnes perekondi, vaid terve rahvus. Nii näib Eestimaa merepiir mitte üksnes geograafilistel, vaid ka ajaloolistel põhjustel vastavat sellele, mida Anthony Smith on tähistanud mõistega ethnoscape ja määratlenud kui „maastikud, mis on looduse historiseerimise ja etnilise mälu territorialiseerimise kaudu laetud poeetiliste etniliste tähendustega" (Smith 1999: 16). Smith kirjeldab selliseid maastikke eeskätt rahvust rajavate müütide vaatepunktist, kuid mõiste on laiendatav ka teiste pöördeliste sündmuste konteksti.

Rand kui piiriala kannab juba intuitiivselt väga tugevat sümboljõudu, mis ühtlasi põhjendab hüpoteesi, et ranna kujutamise viisides väljenduvad ka teoste kesksed tähendused. Piir, liminaalne ruum on igal juhul kõrge semiootilise aktiivsuse paik (Lotman 1999: 12-18). See ühtaegu lahutab ja ühendab, võimaldab dialoogi ja uute tähenduste sündi. Rand kui ruum hakkab modelleerima ka mitteruumilisi tähendusi (vrd Lotman 1991: 92), selle struktuur esineb „mitteruumiliste suhete väljendamise keelena” (Lotman 1999: 106). Ranna motiivi põgenemislugudes saab analüüsida ka Mihhail Bahtini kronotoobi ehk aegruumi mõiste abil (Bahtin 1987: 44-184; vt ka Torop 2000; 2003a; Näripea 2011 jt). Kujutab ju rand endast omamoodi lävepakukronotoopi, mis on „alati metafoorne ja sümboolne, mõnikord avalikult, enamasti aga implitsiitsel kujul" (Bahtin 1987: 176). Bahtin seostab seda kronotoopi just kriisi ja elumurranguga.

Niisiis lähtun alljärgnevas analüüsis hüpoteesist, et rand ei pruugi nendes tekstides muutuda maastikuks kui looduse kirjeldamise viisiks (Kalda 2000: 326) ega tõusta tekstis omaette tegelaseks, kuid omandab igal juhul kujundlikkuse, mis on tekstiterviku seisukohalt tähenduslik. 


\section{August Gailiti „Üle rahutu vee”}

August Gailiti tuntumatele teostele iseloomulikust igatsevast romantilis-sümbolistlikust, kohati nukra koomikaga stiilist (vt ka Annus 2001: 302-303; Vaiksoo 2008: 35) on tema eelviimane romaan omajagu erinev. Selle novellilaadsetest osadest koosnev kompositsioon on küll justkui gailitlik: (sise)monoloogid vahelduvad episoodiliste seikadega. Ka epiteedirohke sõnakasutus, teksti kõla ja tempo ning lauseehitus on äratuntavalt Gailitile omased. Arvo Mägi (1986: 141) on kirjeldanud, kuidas ta „,õnad purskuvad paberile nagu kihutaks neidki metsik tuul soolaste ja rahutute lainete kombel taga". Varasemast Gailitist erineb teos aga eelkõige masendava, ka võrreldes maailmahukuromaaniga „Purpurne surm” (1924) sügavalt lootusetu allhoovusega. Autor paiskab lugeja ette väiklased inimsuhted, rabeleva ja saamatu arguse, ülima tooruse, sõgeda meeleheite, mõttetu eneseõigustuse ja -haletsuse. Tekst, mis algab justkui põhjendusega põgenemisele selle eest, „mis oli kibedam surmast - see oli inimvääritu orjus, terror ja geniaalse täiuseni arendatud vale" (Gailit 2009: 5 , edaspidi ainult leheküljenumber), võrdsustab lahkumise lõpuks siiski reetmisega, rahva moraalse hävinguga, sest ilma kodumaata ei ole vabadusel mõtet ja sisu. Rohked religioossed motiivid ning vanatestamentlikult mõjuv keelekasutus annavad sellele eestlaste saatuse loole omakorda inimkogemust üldistava tooni.

Praktiliselt kogu romaani tegevus leiab paari ööpäeva jooksul aset väikeses kaluripaadis, mis sihtrannani päriselt ei jõuagi, sest paat ise läheb põhja ning romaan lõpeb ellujäänud tegelaste astumisega Rootsi valvelaeva pardale. Mitmekesine karakterite galerii avab paatkonna omamoodi eesti rahva mudelina, kelle hulgas kohtab Henrik Visnapuud (1951: 7) tsiteerides tüüpe alates aatelisest noorest naisest kuni „kristalliseerunud närude prototüübini”. Teisalt on Gailit pannud ühe kodumaale jäänud mehe suhu sõnad: „Kogu rahvas ei mahu ometi paatidesse, too osake, mis jõuab üle vee, pole aga rahvas ega tema teo ja ülesande täitja. Laast, mis raiutakse puult, või kild, mis lendab kivilt, on kõlbuline vaid äraviskamiseks, muuks ei ühtegi" (lk 89-90). Lisaks otseselt tragöödiaga seotud küsimusele - kust võtab inimene jõu, et edasi elada pärast kõige kaotamist - keerlevad tegelaste lood ümber laiemate küsimuste inimese ja teise inimese, inimese ja tema rahva, inimese ja inimkonna, inimese ja Jumala suhetest. Kes peaks kaitsma kodumaad, kes vastutama rahva kestmise eest? Miks ometi juhtus see, mis juhtus? Kõikide tegelaste lugusid saadab toimunu peidetud põhjuste otsimine, usk, et juhtunul peab olema mingisugune sõnum. Gailiti tegelased on kehaliselt küll avamerel viskleval paadil, kuid hinges ja mõtteis kodu- või juba võõral maal. Neid poolusi liidab ja lahutab rand.

Ranna vahendamisel kirjeldab Gailit silmaga nähtavat: esmalt valguse puudumist (lahkuti öö varjul), siis veel paistvaid kodumaa randasid ning rahutuks muutuvaid laiu veevälju. Teisal on viiteid kuuldavatele aistingutele: mootori rõõmsalt podisevale helile, samuti taktiilsetele: külmadele muutlikele tuultele, mille toimel oli „tunda, kuidas läbi paadi küljelaudade käis võppumine ja värin" (lk 6). Ka haistsid nii lahkujad kui paigalejääjad, kuidas hingata oli raske, sest õhk oli otsekui mürgitatud, oli „süsimust pimedus üle kogu Maarjamaa, täis vere kibedat lehka" (lk 5). Sellisest mitut meelt kaasavast ranna vahendamisest hoolimata mimeetilist maastikku tekstis ei teki. Gailiti rand ei elustu äratuntavalt kirjeldatud Eesti mereäärena, vaid lot- 
manliku piirikujundina, mille tuumaks on kaksühtsus ehk piiripealsus. Sellele rannale on korratuks hulgaks laiali pillutud kõrgeim ja madalaim, aga inimene ei leia enam teed nende vahel. Selles piiripealsuses väljenduvad ühtaegu katkestus ja kokkusulamine. Omal ja võõral, heal ja kurjal ei ole enam endisi tähendusi. Tegelasi saadab kummastav aimdus - ühelt poolt hävitab vaenlane kõik oleva, teisalt jäävad kojad, männid, rannakivid ja muugi, mis koduga seostub, paigale.

Tegelaste psühholoogilise segaduse taustal avaldub rannakujundi struktuur, maa ja vee vastuolu Gailiti autorikontseptsioonis üsna selgelt. Maa on väärtuslikum kõigest - vaid omal maal, mille esivanemate töövaev ja veri on „tuhat korda pühitsenud”, saab inimene oma Jumala ja südamega tõeliselt koos elada. Maaga seotud töödest mõtleb Liisu enne minekut ja talumees Alandi veel siiski, kui ümbritsevad merehädast üleni kurnatud olid: „Ta mõtleb sellele, et kartulipõld jäi koristamata, lina kitkumata, osa rukistki hakkides ja peksmata. Ja kui nüüd sõda peaks kestma, kuidas saab siis viljaga?” (lk 192). ${ }^{9}$ Peremees Alandi on oma hoiakuis kõrk, aga ta suus on oluline elutõde: „Talu aga on nagu päike maailmaruumis. Süda organismis, mille vaikimisel järgneb silmapilkne surm" (lk 193).

Kui (oma) maa ees on inimesel kohustus, siis rusuvalt raske ja mõõtmatu mere ees on ta võimetu. Meri on imetletav ja kardetav, kirjeldamatu, ettearvamatu võõras ka rannarahvale, kes temaga igapäevaselt kõrvuti elab. Ometi on mere võimuses inimese olemus alasti kiskuda, sest merel kaob teeskluse toetuspunkt ja kindlustunne. Head ja ilusat on inimese kesta all Gailiti silmis aga kasinalt. Nii kirjeldab poisike Mika kaasteelist: „Rannal omil jalul on inimese moega, aga kui tuleb paati, muutub kohe looma sarnaseks" (lk 145). Kui maa on pidev, siis mere muutlikkus teeb abituks. Ühel hetkel on ta avarus, leivaandja, kaugete maadega ühendaja, siis äkki ületamatu takistus, millest üle saaks aidata vaid see, kes valitud rahva ees mere kahte lehte laiali lööb. Seda aga, et eestlased valitud rahvas ei ole, nendib Martin Vaide juba teose avapeatükis.

Otsus minna maalt rahutule merele ei ole tegelaste elukäigu loomulik jätk, vaid murrang, senise katkestus. Nii minevik kui tulevik otsekui kaovad - ühel ei ole enam tähtsust, teine on täiesti tundmatu. Ka Bahtin (1987: 176) on ühe lävekronotoobi tunnusena välja toonud: „[a]eg selles kronotoobis on tegelikult vaid hetk, ta justkui ei evigi kestust ja seisab väljaspool biograafilise aja kulgu." Suure muutuse lävel ei suudeta käituda ega tegutseda nii, nagu seni on tehtud, õieti ei osata kuidagi reageerida ega midagi tundagi. Värisevad käed, katkenud mõtted ja laused, hädised selgitused nii paadisolijatelt kui ka paigalejäänutelt, reeturlikest kaaslastest maha jäetud avasui rannal seisvad eesti sõdurid, kes ei taipa vihastudagi või „lahkujaile mõnd kuuli tervituseks ja hüvastijätuks tagant järele saata" (lk 8).

Ranna kui lävega seostub tekstis ka kahe tegelase - Enn Tormeti ja Aasa Leedi - pöördeline kogemus, mida mõlemad kirjeldavad taas inimeseks saamisena pärast kohutavaid kannatusi. Just rannal sai Aasa Leet tagasi oma nägemisvõime, mis oli hõlmavam silmale nähtavast. Samuti jooksevad tema prohvetlikus nägemuses rannal ringi ta enda sünnitatud uue rahvasoo arvu-

${ }^{9}$ Samasisuline lause kordub nii paar lehekülge hiljem kui iseloomulikult ka näiteks Kruusvalli „Pilvede värvide” (1986: 83) ühes kuulsaimas repliigis ema suus: „Ülehomme pidime hakkama lina kitkuma. Rukkivihud tuleb sisse vedada. Nisu niitmine algab. Rehepeks. Tädi juba lapib kottisid. Kartulivõtt." 
kad lapsed. Seal peitubki Visnapuu hinnangul see lootusekiir, mis Gailiti ehmatavas pessimismis suuremale osale lugejaist märkamatuks jäi. Tee sinna on aga mõistagi pikk.

\section{Sulev Keeduse „Somnambuul”}

Nagu viidatud, vahendab Keedus põgenemise lugu distantsilt nii ajalises kui ka isiklikus plaanis. Oma ajaloo (re)konstrueerimine erinevates meediumides ja modaalsustes on iseseisvuse taastanud riigi jaoks loomulik autokommunikatiivne akt. Filmikeeles käsitlesid eestlaste ajaloo pöördehetki näiteks ka „Somnambuulist” aasta varem valminud Elmo Nüganeni „Nimed marmortahvlil” ja kaks aastat hilisem Ilmar Raagi „August 1991”. Ehkki nimetatud portreteerivad eestlaste lugu võrreldes Keedusega eksplitsiitsemalt, on kõik need filmid vaadeldavad kultuuri enesekirjeldustena, mille roll on noore riigi elus eriti keskne. Olgugi et Keedus ei seo oma teost Gailiti romaaniga ega viita otseselt ühelegi Gailiti aja mäletamisviisi aspektile, lõimuvad Keeduse ja Gailiti lood ühise ainese kaudu vastuvõtva kultuuri mälus ometi.

Kui Gailiti stiili iseloomustades kirjeldab Mägi tema väljendusvahendite - sõnade - kõrgendatud tormlemist, siis „Somnambuul” näib selle täielik vastand. Erinevus ei seisne Keeduse argises realistlikkuses, vaid Rein Kotovi ülesvõetud mõjusalt komponeeritud rahulike, pikkade ja aeg-ajalt otsekui ujuvate kaadritega stiilis. ${ }^{10}$

„Somnambuuli” esimeseks märgatavaks tunnuseks on läbiv hall koloriit. Kogu atmosfäär nii sise- kui ka välisruumides on kõle, hämar ja hüljatud, vaatajat saadab algusest lõpuni külmatunne, mida ei leevenda ka kevadvalguses filmitud stseenid. „Somnambuuli” tegevusruumi - majakaümbruse - olulisemaid tunnuseid on just eraldatus. See mereäärne paik mõjub kui maailma serv, millest edasi tuleb vaid tühjus, olgugi et isa taob linnu jalarõngale tähise „Estonia Matsalu”. Keeduse ranna trööstitus erineb Gailiti romaani asustatud rannast, mille kivide ja mändide vahele jäi rohkesti majapidamisi, kuhu jõudsid kokku teed linnast, sisemaalt ja teistest ümbritsevatest küladest. „Somnambuuli" rand on suletud ruum, teed selleni nagu ei tookski ja majapidamisi on raske ette kujutada. Üksikud hooned ja aiad, roostes postkastid ning mõned dialoogikatked küll viitavad, et varem on selles paigas olnud liikumist ja elu, aga filmi tegevuse ajaks on nende kajagi praktiliselt haihtunud. Õigupoolest oligi elu ja värvi siin mitte siis, kui küla ja rahvas veel elasid, vaid siis, kui oli ema, kelle „nahk oli nagu valgust täis”. Vähemalt Eetla mälus on nii.

Mälukujutisi vahendatakse filmis aga Eetla somnambuulsete monoloogide, mitte helilis-pildiliste stseenide kaudu, nagu see oli Keeduse varasemas filmis „Georgica”. Viimasel juhul hakkasid mälestused kontrastsete kujutistena filmiteksti rütmistama, kuid „Somnambuul” mõjub ühtlaselt külma, tühja ja soolase lagamikuna, kestva seisundina, mis aktualiseerub tühjaks jäänud ranna kujundis. Film on küll aastaaegade kaudu triloogiaks liigendatud, kuid selle osad toimivad ühesuunalise kulgemisena, haiguse süvenemise etappidena.

„Somnambuulis” on palju teatripärast, eelkõige Eetla monoloogide tõttu. Monoloogide sisu ei ole seejuures realistlikult argine ega psühholoogiliselt loo-

${ }^{10}$ Keeduse autoristiili on pikemalt küll „Georgica” pinnalt, kuid üldistavalt käsitlenud Katre Pärn (2011). 
mulik, sest neiu tollases rannakülas nii ei rääkinud ega mõelnud, isegi mitte juhul, kui polnud päris terve mõistusega. Väljaöeldava teksti sisuplaani võiks selles filmis kirjeldada kirjanduslikuna, ent Eetla osatäitja Katariina Laugu intonatsioon ja miimika tekitavad iseomase rütmi ja meloodia, annavad sõnadele intensiivsuse, mis üksnes kirjasõna vahenditega ei teostuks. Monoloogi kui dramaturgilise võtte funktsiooniks on „Somnambuulis” rõhutada tegelase võõrandumist temaga juhtunust. Eetlal on tung jutustada, sest ilma selleta on võimatu mõista, olgugi et ta ise on haige ja niikuinii ei mõista ega erista ilmset unenäolisest. Tema lugudes segunevad ta oma kogemused ja ema omad, tuleviku vormis räägib ta mineviku sündmustest ning mineviku vormis alles eesseisvast. Seegi joonib alla reaalsuse ja ebareaalsuse piiri hägustumist. Õigupoolest on sõnaga, „somnambuuliga” seotud ka filmi algimpulss. Tõukeks ei olnud see mitte üksnes oma semantikaga, viidates haiguslikule uneskõndijaseisundile, vaid ennekõike kõla poolest, mida võib kirjeldada onomatopoeetilisena lämbuja meeleheitliku häälitsemisega (Torop 2003b). Nii võiks „somnambuuli" siin pidada enamgi luule- kui proosakeele sõnaks.

Filmi teatripärasust omakorda lõhuvad intensiivsed lähivõtted ning kaadrid rannast ja rannaastangult paistvast merest, kus vee ja maa piir on pidevas liikumises. See toimib pildilise ekvivalendina eelkirjeldatud määratlematusele. Kõikides rannakaadrites on alati inimene ja mingisugune tegevus, sageli raskendatud tegevus. Kõikides rannaepisoodides esineb korduva motiivina tegelase kukkumine, koperdamine, libastumine ehk tasakaalukaotus, milles taaskord ilmneb paralleel rahva jalgealuse kadumisega. Juba avakaadrid on filmitud rannal ja kujutavad Eetla naasmist. Noor naine tuleb täiesti kummaliselt - riides, tilluke kohvrike käe otsas - merest. Esialgselt plaanitud ja üleski filmitud massistseen inimeste pagemisega jäeti, erinevalt Kõivu kuuldemängust, lõppversioonist välja. Seetõttu pole kohe ka võimalik aru saada, kust ta täpselt tuleb või kuhu läheb.

Pildiliste vahendite kõrval on filmikunsti teiseks, Keedusele olulisemakski ${ }^{11}$ väljendusvahendiks heli. „Somnambuuli” akustiline maastik luuakse Eetla hääle, raadiopinina ning Helena Tulve rütmitu ja katkendliku muusikaga. Õieti moodustub ka üks filmi raame heli kaudu, meremühasse sulanduvad raadiosignaalid on kuuldavad veel enne, kui pilt ekraanile tuleb, ning raadioragin jätkub kogu viimase stseeni jooksul ja pärast seda lõputiitrite taustal. Segased raadiohelid ühe juhtmotiivina ühtaegu ühendavad ja lahutavad ranna ruumi meretagusega. Rootsist oodatakse teateid, Kasper võtab läbi ragina vastu morsesignaali, isa Gottfried krutib asjatult sahisevaid kanaleid. Ainsad infokillud, mis läbi kahina pärale jõuavad, on aga Moskva kellaaeg ja teade, et sõda on läbi. Samaaegselt rõhutatakse niisiis rannaruumi väljapääsmatut eraldatust.

Ebamääraseid raadiosignaale võib vaadelda rannakujutiste helilise ekvivalendina, kuivõrd samasugune määratlematus kordub ranna vahendamisel valitud kadreeringutes. Neis ei ole üsna sageli võimalik täpselt aru saada, kus pool on meri ja kus maa. Kaadreid, milles nende vahel on üks selge piir, mis liigendaks maa ja mere paremaks ja vasakuks või ülemiseks ja alumiseks, praktiliselt ei ole. Vee ja maa vastandumine ei ole filmis seega niivõrd

${ }^{11}$ Keedus selgitab intervjuus Peeter Toropile: „Ehitasime filmi ruumi eeskätt helilise ruumina. Kinos loob atmosfääri lõpuks siiski see, mida me kuuleme, sest näeme me vaid pealispinda" (Torop 2003b). 
tugev kui Gailiti romaanis, olgugi et intuitiivselt võiks arvata, et visualiseeritud rand on oluliselt konkreetsem ja seda konkreetsust pole võimalik vältida. „Somnambuulis” iseloomustab vee ja maa piiri aga eelkõige just määratlematus, kõikehõlmav painav selgusetus. ${ }^{12}$ Nii rõhutatakse ka jäämise ja lahkumise selget eristamatust. Võõrus, mis tungis kodurannale, võis kõik oleva muuta veel võõrastavamaks kui lahkumine.

Nagu Gailiti romaani, võib ka Keeduse filmi pidada pessimistlikuks, olukorra sügavat traagikat rõhutavaks, ent seejuures ei võta Keedus hukkamõistja ega õigete vastuste teadja positsiooni. Autorina analüüsib ta inimese tasakaalutuse traagikat selles murdepunktis vee ja maa piirialal, aga ta ei anna ega võta lootusi edasise suhtes, erinevalt Gailitist, kes näeb, et kui maaga taas kontakt saadakse ning seda kaudu ka Jumala ja merega lepitakse, on lunastust loota. Samuti ei ole Keeduse rannakujund erinevalt Gailiti omast sisemiselt selgelt liigendatud. See on teadlikult ebamäärane sulam, mida korratakse erinevates modaalsustes (helis, sõnas, tegevuses, kadreeringutes, pildi koloriidis) ja millega on otseselt seotud tasakaalu kaotuse motiiv.

\section{Eerik Haameri „Perekond vees”}

Põgenemistelainest kolm aastat varem valminud maali käsitlemine põgenemist mäletava mäluaktina on problemaatiline ettevõtmine. Kahtlemata ei sündinud teos teadlikult üksnes ülemere põgenemisega seostatuna, olgugi et juba 1941. aastal oli meritsi lahkujaid. Maali kujunemine paadipõgenike loo kujutajaks on hilisema ülelugemise tulem, mis oli juba teadlik Haameri enda põgenemisest ning laiemalt eksiilisuundumise ulatusest ja aimas selle mõju eesti kultuurile. Samas ei assotsieeru „Perekond vees” ka ainuüksi paadipõgenike episoodiga, vaid seostub laiemalt väikerahva kaitsetusega, mille üheks traagiliseks väljenduseks oli selle liikmete põgenemine oma isade maalt.

Eerik Haamer kuulus uusrealistidest ${ }^{13}$ pallaslaste hulka (Abel 2010: 461), kelle loominguline siht ei olnud elutõe eest näilisuse maski mahakiskumine, vaid pigem argise elu empaatiline estetiseerimine. Haameri varasemad tööd on tumedas varjundirikkas ja maalähedases värvigammas, tugevate hele-tumeduse kontrastidega karged ja ekspressiivsed maalid tõsiste sitkete randlaste elust. Inimkujud neil maalidel on kunstnikule varakult omaseks saanud võttena (Kõiv 2008: 22) otsekui pikaks venitatud. Eksiilis muundusid Haameri toonid kirkamaks ja dekoratiivsemaks ning pindade asemel tõusid esile selgete kontuuridega figuurid. Ka teemad omandasid ajapikku uusi, sotsiaalkriitiliselt koomilisi, groteskseidki meeleolusid. ${ }^{14}$

Mõlemal pool merd valminud töid iseloomustab lõuendi suuremõõtmelisus, millega kõlas eriti kokku varase Haameri eepiline motiivikäsitlus. Kujutades

${ }^{12}$ Segaduse motiiv kordub ka teistes märgisüsteemides, nende hulgas Eetla kostüümides: riided on tihti pahupidi, erinevatesse oludesse sobivad esemed üheskoos seljas, jalas vaid üks sukk jne. Kostüümikavandid koos kunstnik Mare Raidma kommentaaridega on nähtaval Eesti Filmi Andmebaasis (http://www.efis.ee/et/filmiliigid/film/id/382/fotod/719).

13 Tiina Abel (2010: 461) käsitleb uusrealiste eelkõige figuurimaalist ja looduslähedusest innustunud suuna esindajatena.

${ }^{14}$ Ehkki kunstniku käekirja muundumist võib täheldada juba viimastel kodumaa-aastatel, võib nõustuda Haameri uurija Reeli Kõivuga, kes viitab, et alates kodumaalt lahkumisest ehk 1944. aasta sügisest on olemas otsekui kaks erineva kujutamislaadi ja temaatikaga Eerik Haameri nimelist kunstnikku, üks Eestis, teine Rootsis (Kõiv 2008: 10). 
rannarahvast nende igapäevaolustikus ja argitegemistes, tõstis kunstnik nad oma kujutusviisiga argisest kõrgemale, pühitsedes või mütologiseerides igapäevase töö. Filosoofiliselt üldistavas laadis, millele juhivad tähelepanu kõik olulisemad Haameri-käsitlused (Levin 1986; 1988; Kõiv 2008), on tunda empaatiat ja poolehoidu kujutatute vastu. Ka lihtsatest inimestest, kes küürutades kivise pinna kohal oma kasinat toidust kokku kaabivad, õhkub uhkust ja väärikust. Seetõttu on Tiina Abel (2010: 482) Haameri ruume kõrvutanud ka Bahtini idüllikronotoobiga.

Kompositsioon „Perekond vees” on Haameri üldistusvõime paremaid näiteid. Ilmselgelt ei ole see maal üksnes ühe perekonna portree, ehkki kujutab perekonda. Need on kaitsetud ja kõhklevad, ent ometi ühtehoidvad ema, isa, poeg ja pisike tütar, seismas kaldaäärses vees, kätega püksisääri ja seelikusabasid üleval hoides. Maalil kujutatu on kui hetk enne põgenemist, olgu füüsilisse või vaimsesse eksiili, kui veel ei ole teele asutud, vaid seistakse täielikus suruseisus madalas ja liikumatus kaldaäärses vees. Ema ja tütar vaatavad enese ette vette, isa ja poja pilgud on aga suunatud emale, kes on igakülgselt kompositsiooni kese. Ehkki pooleldi lahtinööbitud pluusi ja tõstetud seelikut võib tõlgendada ka viitena vägistamisele, äärmuslikule vägivallaaktile, ei näe me naise ilmes ometi ahastust. Tema vaoshoitud kurbusest tungib läbi jõud ja sitkus, mis on rusuvas ja väljapääsmatus olukorras ainsaks edasikestmise lootuseks. Olgugi et „Perekonnal vees” on naise pea uhkest püstiasendist langetatud ning jalad ei puuduta enam jõudu andvat maad, meenutab ema oma hoiakult ometi keset tühermaad last imetavat naist autori 1940. aasta maalil „Noor ema” (1940, EKM M 414), keda Mai Levin (1988: 34) on nimetanud Eesti madonnaks. Ka tüdrukuke, ülejäänud ühekasvulisest perekonnast palju pisem ja seega veelgi kaitsetum, sarnaneb mõneti varemkujutatuga, samuti all paremal nurgas seisva tütrega 1940. aasta maalil „Evakueeritavad” (EKM M 1048). Teemalt ühinevad need maalid eestlastega sündinud tragöödia võrdkujuks. Inimestel nendel piltidel ei olnud muud valikut kui ülekohtule alistuda, kuid päriselt alla ei anna nad kunagi.

Nagu viidatud, on Haameri Eesti perioodi loomingule iseloomulik looduse ja inimese ühtesulandumine. „Perekonnal vees” täidavad inimfiguurid praktiliselt kogu maalipinna ning keskkond jääb vaevuaimatavaks. Tooni poolest sulanduvad inimeste kehakatted kokku mustjaspruuni veega, millest õigupoolest annavad aimu vaid lainerõngad poja ja tütre jalgade ümber. Seljataha jääv maa on oluliselt heledam. Hallikasroheline maapind, mis on maalitud ülaserva inimeste peade taustale, ei meenuta konkreetset maastikku, võib üksnes aimata rohetavat kõrgendikku ja ehk talumaja selle otsas. Kompositsiooniliselt on Haamerile omane kõrge horisont (Kõiv 2008: 105), kuid nimetatud maalil on näha vaid killuke helesinist taevapiiri vasakus ülanurgas ning imepeenike joon ülaservas. Silmapiir on sellega peaaegu suletud.

Teos tervikuna on antud toonirikkas pruunikas-rohelises gammas, tumedalt pinnalt tõusevad esile vaid inimeste ihud ja ema särk, risti helendava rannaliivaribaga. Pintslitehnikalt on maal varasele Haamerile iseloomulikult lai ja pastoosne, maali pind krobeline, kohati kraabitud. Otsekui maaliraami surutud inimfiguurid ning nende frontaalne asetus väga lähedal ja suures plaanis, otsekui vastu seina, rõhutab olukorra suruseisu. Haameri rannavaadetele on üldjuhul omane kõrgelasetsev panoraamne vaatepunkt ning kompositsioonilahenduselt inimeste paiknemine esiplaanil kitsal maaribal, 
taamal sulamas kokku taevas ja meri (Levin 1988: 30). „Perekonnal vees” on see vaatepunkt tagurpidi pööratud, merele viidud: inimeste selja taha jääb oma ja turvaline, ees aga ootab hirmutav tundmatus. Haameri rand on niisiis vaid aimatav maariba inimeste selja taga, vastu tahtmist mahajäetud kodu ning kaldavesi, mis tumedalt toonilt lõuendi raami surutud ilmekate inimfiguuridega kokku sulab. Kõigi kolme autori tekste ühendab seega õhutuse motiiv: romaanis kirjeldatakse kibedast verelehast mürgitatud õhku, filmis räägitakse lämbumisest, maalil aga puudub kompositsiooniliselt hingamisruum. Mereranna vahendamise puhul on õhupuudus omamoodi kummastav, kuivõrd üldjuhul seondub rand enam just avaruse ja vabadusega, paigaga, kus on kerge hingata.

Esmaesitlusel 1941/42. aasta vahetusel Tallinna Kunstihoone jõulunäitusel kandis maal pealkirja „Kompositsioon”. Ajalehes Eesti Sõna ilmunud arvustuses peatub kriitik esimesena ja kõige pikemalt just Haameri teosel, ent kas suutmata või julgemata taibata selle avaramat sõnumit, seostab inimestegrupi uppunu leidnud või paadile mineva saunarahvaga (J.R. 1941: 8). Mai Levin on tööle omistanud aga sügavama religioosse tausta, kirjeldades pildil olevat pühitsemise või ristimistalitusena (Levin 1988: 37). Sellist tõlgendust toetavad nii eksplitsiitselt religioosse teemaga seotud tööd Haameri varasema loomingu hulgas kui võimas proovilepanek, mis väljendub kujutatute ilmeis. Eerik Haamer ise on maali kommenteerinud aga lausega: „See on meie vabariigi õnnetuse algus: Kui meie rahvas enam ei teadnud, kus olla, mida teha või kuhu minna" (tsit Uuskyla 1997: 4). Kunstniku suhe sellesse rahvasse on ilmselgelt soe ja kurbuses kaastundlik.

Sarnane hoiak kordub ka otsesemalt pagemisteekonda kujutaval õlimaalil „Põgenemine” (1945, Eesti Komitee, Stockholm), millel ehk samuti on perekond: kaugusesse, tumerohelisele merele suunatud pilguga mees, rinnalapsega ema ja vanem naine tüdrukuga süles. Haamerile omast paksu värvikihti, mida Tiina Abel (2010: 482) on tabavalt võrrelnud maamullaga, „Põgenemisel” ei ole - teos on maalitud läbikumavates tumedates toonides, mille pinnalt tõusevad esile vaid naiste ja tüdruku valged pearätid. Diagonaalse kompositsiooniga kujutatud paatkond, kelle keskmeks taaskord imetav ema, on täielikult lainete meelevallas. Raskete roheliste vete tagant ei paista loomulikult ka päästvat rannajoont, ei kodu- ega võõra maa oma, inimesed on kõigest omasest eemale rebitud, pimedas tundmatuses, mures, kuid kõigest hoolimata elu küljes kinni.

„Üle rahutu vee” esmatrüki söepliiatsi ja akvarellidega teostatud kaanekujunduses kordas Haamer nii „Põgenemise” motiive ja kompositsiooni kui ka tonaalsust. Kümmekond aastat hiljem kajab „Põgenemine” vastu aga Haameri „Kalevipoja” illustratsioonilt (ilmus 1954. aastal Torontos). Kui Kristjan Raua Kalevipoeg suundub maailma otsa võimsa ja viikingliku „Lennukiga”, siis Haameri söepliiatsijoonistusel toimub see retk vete meelevallas aerupaadiga, mille sõudjate lihased on viimseni pingul, taamal ohtlik Sädemete saar, nii nagu see oli tuhandete eestlaste teekonnal 1944. aastal. Sellise korduse kaudu asetub Haameri „Põgenemine” ka „Kalevipoja” intertekstilisse ruumi ning kunstniku põgenemist kujutavad teosed põimuvad veelgi laiemasse kultuuriteksti.

Kõiv (2008: 119-120) on Haameri mälestustele viidates põgenemisega seostanud ka teose „(Tormi)Näkk” (1946, erakogu, Eesti), mis kujutab Haame- 
ri puhul täiesti uues, sümbolistlikus laadis mere sõnulseletamatut ja hirmsat loomust. Kaudsemalt, meeletuse ja kodust kihutamise motiivi kaudu, on pagenduse teemaga seotud aga ka „Väljatõugatu” (1945, Viinistu Kunstimuuseum) (Üürike 1963: 31).

Kõik viidatud Haameri uurijad on maali „Perekond vees” välja toonud mõjusa saavutusena kunstniku loomingutervikus, ent laiemalt on seda paadipõgenemise ning teiste 1940. aastatel eesti perekondadele osaks langenud ülekohtuga seostama hakatud just iseseisvuse taastamise järgselt. Just rannapiiril seisjad - mitte juba merel olijad - on saanud põgenemise tähenduse kujustajateks. Mitmekümneaastaselt distantsilt mõjuvad 1940. aastate esimesed kolm-neli aastat teineteisele palju lähemal seisvana kui vahetult järgnenud kümnendeil ning eraldiseisvad sündmused sulanduvad eemalt vaadates ühenimeliseks tervikuks. Nii on Haameri maali tõlgendamiste ja ülelugemiste lugu ka laiemas teoreetilises kontekstis huvitavaks näiteks kultuurimälu toimimise mehhanismi keerukast mittelineaarsest toimest.

\section{Ranna invariant}

„Üle rahutu vee”, „Somnambuul” ja „Perekond vees” on kolm teksti, mis vahendavad eestlaste meritsi põgenemise lugu, ent ükski neist ei ole iseenesest sündmustikukeskne. Gailiti romaan on põgenemise psühholoogiline ja filosoofiline lahkamine, mis avab süvitsi põgeneja koondportree, Keeduse film mõjub 129 minuti pikkuse seisundina, milles peegeldub ajastu määratlematu äng ja selle mõju inimesele, Haameri maal aga kujutab üht hetke, millesse on kontsentreeritud väikerahva inimlik kaitsetus ülekohtu ees.

Rand on nendes tekstides esiteks narratiivne ruum (lahkumise, jäämise ruum) ja teiseks sümbolruum. Kui Gailitil on tähtis maa ja vee vastandus, kummalegi omistatakse teatud omadused ja väärtused ning seotakse need kindla struktuuriga binaarsesse maailmapilti, siis Keedus rõhutab just tabamatut piirjoont maa ja vee vahel. Seejuures ei ole kumbki poolus kuidagi täpsemalt tähendustatud, vaid tähtis ongi piir, mida pole võimalik selgelt määratleda - vesi loksub kaldale ning tõmbub tagasi ja nii lõputult. Haamer ei ole seda piirjoont aga üldse kujutanud, maali pea täielikult kattev perekond seisab mustjas vees ning hele rannaviir jääb vaid aimatavana nende seljataha.

Looduse otsekui ükskõiksus inimesega toimuva suhtes on nende põgenemistekstide invariantne tunnus: Gailit võrdleb merd paadi ümber süüdimatult palli pilduva lapsega, Keeduse filmis avaldub see eriti kujukalt maalilistes merekaadrites ning imekaunis päikesetõusus inimese murdumishetkel, Haameri meri on ühtlaselt ja liikumatult tume ja raske, andmata tuge ega vastuseid. Perekonna kaitsetust ei rõhuta kunstnik mitte nende väiksusega laiade võimsate merelainete vahel, vaid tõstes inimeste ekspressiivsed ilmed suurde plaani, tuues nende suruseisu lähedale.

Rand kui transmeedialine invariant on kõigis vaadeldud tekstides seotud rahva identiteedi kaotusega - nendel randadel on inimesed, kes on oma maalt välja merre aetud ja kellel ei ole kuhugi minna ega õigupoolest enam ka kodu, kuhu paigale jääda. Vastavalt iga kunstikeele vahenditele varieerub selle tähenduse esitus sõnakasutuses ja metafoorides ning lause rütmis Gailitil; katkendlikes helides, külmas koloriidis, valitud kaadrikompositsioonides 
ja tasakaalukaotuse motiivi kordumises Keedusel; tumedates toonides, pildi raami surutud ilmekates inimfiguurides Haameril. Need variatsioonid on osa paadipõgenemiste mentaalsest tekstist eestlaste kultuurimälus. Emotsionaalselt värvingult on tekstid erinevad, kuid huvitaval kombel näevad kõik kolm autorit rahva saatuse otsustajana rannal seisvat naist, kelle vastupidamisest sõltub, kas rahvas jääb kestma või hukub lõplikult. Mehelik ja mõistusepärane aegruum on neis katkestatud, määratlematus ja piiripealsus on naiselik printsiip.

Vajadus määratleda ja mõtestada iga kunstikeele sisemine, seda teistest eristav identiteeti loov omapära on kultuurile iseloomulik, kuid eristumisega samaaegselt toimib ka kunstikeelte lõimumine. Maailm ja selle ajalugu ei ole ammendavalt kirjeldatavad mitte üheski keeles eraldi ja sestap on mitmekeelsus nende mõtestamisel vältimatu (Lotman 2010: 32). Ajaloosündmuse kui teksti paljukeelne kordamine ehk ülelugemine kultuuris on viljakas, sest aitab sügavamalt mõista nii olnut kui ka lugeja enda - kultuuri - tõlgendavat potentsiaali. See ühelt poolt säilitab möödunu elevana, sidustab ja kinnistab kultuuri identiteeti. Teisalt on taoline mõtestamisprotsess loomult ammendamatu ning erinevate kultuurikeelte võimalike põimumiste reservuaar põhjatu. Mida mitmekesisemad on kultuuri vahendid enese ja eneses toimuva mõistmiseks ja mõtestamiseks, seda rikkam on kultuur, sest metakeeleline ja metatekstiline mitmekeelsus annab aluse järjest uute tähenduskihtide avamisele ning tõlgenduste sügavusele. Nii võiks kokkuvõttes osutada veel Ann Rigney (2005: 20-21) käsitlusele ning nõustuda, et paljukeelne kordamine on elava transmeedialise kultuurimälu toimemehhanism.

\section{Kirjandus}

A b e 1, Tiina 2010. Realismi moderniseerimine. - Eesti kunsti ajalugu. 5. kd, 19001940. Koost ja toim Mart Kalm. Tallinn: Eesti Kunstiakadeemia, lk 459-486.

A d s o n, Artur 1994. Lahkumine. Ülestähendusi viimasest aastatosinast. Tallinn: Eesti Raamat.

Ann u s, Epp 2001. August Gailit. - Epp Annus, Luule Epner, Ants Järv, Sirje Olesk, Ele Süvalep, Mart Velsker, Eesti kirjanduslugu. Tallinn: Koolibri, lk 299-308.

A r r o, Karl 1945. Põgenemine. - Eesti põgenikud Rootsis sõnas ja pildis, 19441946. Toim Arvi Moor, Edgar Tibbing, Hans Vilper, Voldemar Brun. Borås: Eestlust jäädvustav toimkond Boråsi Eesti Seltsi juures, lk 10-18.

B a h t i n, Mihhail 1987. Valitud töid. Tallinn: Eesti Raamat.

G a i li t, August 2009. Üle rahutu vee. Tallinn: Eesti Päevaleht.

H e r m a n, David 2004. Toward a Transmedial Narratology. - Narrative Across Media: The Languages of Storytelling. Toim Marie-Laure Ryan. LincolnLondon: University of Nebraska Press, lk 47-75.

J.R. (pseud) 1941. Kunstinäitus Kunstihoones 14. XII 1940 - Eesti Sõna 4. I, nr $20, \mathrm{lk} 8$.

Ka ld a, Maie 2000. Suletud ruum tegevuspaigast kujundiks. - Mis mees ta on? Tallinn: Underi ja Tuglase Kirjanduskeskus, lk 326-363.

Ka st e r p a lu, Margus 2009. Järelsõna: Üks leegitsev süda üle rahutu vee. August Gailit, Üle rahutu vee. Tallinn: Eesti Päevaleht, lk 241-255. 
K i r m e, Kaalu 2007. Muusad ei vaikinud: kunst Eestis sõja-aastail 1941-1944. Tallinn: Kunst.

K i r s s, Tiina 2002. Põgenemine ja trauma. - Looming, nr 12, lk 1870-1880.

Kr u u s p e r e, Piret 2008. Sissejuhatus. - Eesti kirjandus paguluses XX sajandil. Toim Piret Kruuspere. Tallinn: Underi ja Tuglase Kirjanduskeskus.

K r u u s v a 1 l, Jaan 1986. Jõgi voolab. Pilvede värvid. Tallinn: Eesti Raamat.

$\mathrm{K} \mathrm{u} \mathrm{m} \mathrm{e} \mathrm{r-} \mathrm{H} \mathrm{a} \mathrm{u} \mathrm{k} \mathrm{a} \mathrm{n} \mathrm{õ} \mathrm{m} \mathrm{m,} \mathrm{Kaja} \mathrm{2011.} \mathrm{Teise} \mathrm{maailmasõja} \mathrm{aegne} \mathrm{eestlaste} \mathrm{sund-}$ migratsioon läände. - Acta Historica Tallinnensia, nr 17, lk 95-109.

Kõ i v, Reeli 2008. Eerik Haamer. Tartu: Tartu Kunstimuuseum, Kumu Kunstimuuseum.

Levi n, Mai 1986. Eerik Haamer - portreevisandid. - Looming, nr 8, lk 11431147.

L e vi n, Mai 1988. Eerik Haameri varasem looming ja RKM-i kollektsioon. - Kogude teatmik: artiklid 1986. Tallinn: Eesti Kunstimuuseum, lk 28-52.

L o t m a n, Juri 1985. Mälu kulturoloogilises valguses. - http://kodu.ut.ee/ silvi11/ lotmanitolked/malu\%20kulturol.htm [26. VII 2013.]

L o t m a n, Juri 1991. Kultuurisemiootika: tekst - kirjandus - kultuur. Tallinn: Olion.

L o t m a n, Juri 1999. Semiosfäärist. Tallinn: Vagabund.

L o t m a n, Juri 2001a. Kultuur ja plahvatus. Tallinn: Varrak.

Lotman, Juri 2001b. Universe of the Mind: A Semiotic Theory of Culture. London-New York: I.B. Tauris.

L o t m a n, Juri 2004. Filmisemiootika. Tallinn: Varrak.

L o t m a n, Juri 2010. Kultuuritüpoloogiast. Tartu: Tartu Ülikooli Kirjastus.

M a tj u s, Ülo 1998. Minnes isade maalt. Järelsõna. - August Gailit, Üle rahutu vee. Tartu: Ilmamaa, lk 297-303.

M o o r, Arvi, Tibbing, Edgar, Vil p e r, Hans, B r u n, Voldemar 1945 (toim). Eesti põgenikud Rootsis sõnas ja pildis, 1944-1946. Borås: Eestlust jäädvustav toimkond Boråsi Eesti Seltsi juures.

M ä gi, Arvo 1986. Aeg kirju ei kuluta: vaatlusi kirjandusest ja ajaloost. Lund: Eesti Kirjanike Kooperatiiv.

N är i p e a, Eva 2011. Estonian Cinescapes: Spaces, Places and Sites in Soviet Estonian Cinema (and Beyond). Doctoral thesis. Tallinn: Eesti Kunstiakadeemia.

O n o p e r, Annemaria 2008 (koost). Eerik Haameri bibliograafia. Tartu: Eesti Kirjandusmuuseumi Arhiivraamatukogu.

P är n, Katre 2011. Autori ilmnemine stiilis: Sulev Keeduse „Georgica”. - Kunstiteaduslikke Uurimusi, kd 20, nr 3-4, lk 144-165.

R i g n e y, Ann 2005. Plenitude, scarcity and the circulation of cultural memory. Journal of European Studies, kd 35, nr 1, lk 11-28.

R i s t i k i vi, Karl 1951. Üks ülesõidulugu. - Välis-Eesti, nr 24, lk 6.

S m i t h, Anthony 1999. Myths and Memories of the Nation. New York: Oxford UP.

T o r o p, Peeter 2000. Identiteedi aegruumist. - Teater. Muusika. Kino, nr 1, lk 62-66.

To r o p, Peeter 2003a. Bahtin sotsioloogilise ja ajaloolise poeetika vahel. - Vikerkaar, nr 7-8, lk 104-111.

T o r o p, Peeter 2003b. Interview With Sulev Keedus. - Estonian Culture, nr 2. http://www.estinst.ee/publications/estonianculture/index3.html [26. VII 2013.]

T o r o p, Peeter 2008. Multimeedialisus. - Keel ja Kirjandus, nr 8-9, lk 721-734.

U s penski, B. A., Iva nov, V. V., Toporov, V. N., Pjatigorski, A. M., L o t m a n, J. M. 1998. Kultuurisemiootika teesid. Tartu: University of Tartu. 
U u skyla, Wello 1997. Eerik Haamer ja tema poliitiline protestimaal. - Eesti

Päevaleht = Estniska Dagbladet 3. IV, nr 13, lk 1, 4.

V a i k s o o, Jaanus 2008. August Gailit. - Eesti kirjandus paguluses XX sajandil.

Toim Piret Kruuspere. Tallinn: Underi ja Tuglase Kirjanduskeskus, lk 35-41.

V i s n a p u u, Henrik 1951. Müüt uuest Noa laevast. - Vaba Eesti Sõna 17. III, nr $11,1 \mathrm{k} 6-7$.

Ü ü ri ke, Madis 1963. Kunstniku sisemisest tungist. Erik Haameri varahommikusi pihtimisi. - Mana, nr 1, lk 30-31.

\section{The transmedial nature of cultural memory: The coast in the artistic texts inspired by the refugee boats trying to escape World War II}

Keywords: transmediality, August Gailit, Sulev Keedus, Eerik Haamer, coast motif, escape of 1944

The article assumes that history is kept in cultural memory by reduplication into different languages or media. Each new duplicate version includes a variable part influenced by its author's contemporary socio-cultural background as well as by the particular medium or language used. On the other hand, transmedia analysis enables to find the invariable core contained in all of the versions.

One of the repeatable wholes in Estonian cultural memory is made up of the artistic texts mediating the escapes over the sea in 1944. The article analyses fragments of three relevant works, namely, August Gailit's novel Üle rahutu vee („Over troubled waters”, 1951), Sulev Keedus's feature Somnambuul (,Somnambulance”, 2003) and Eerik Haamer's oil on canvas Perekond vees („The family in water”, 1941).

The focus of the comparison is the coast motif. This is, firstly, the space where the events are set and, secondly, a symbolic space with a strong poetic potential, which is perceptible even intuitively. The coast is a border zone between the own and strange, the past and the future; but it is also a memory site harbouring hope as well as despair, both for an individual and the whole nation. Thus, in all three works the motif can also be associated with a loss of personal and national identity, a theme varied by each author according to his own artistic means. Those variations underline the inevitable polyphony of recollection, which is the underlying mechanism of transmedial cultural memory.

Maarja Ojamaa (1983), MA, University of Tartu, Department of Semiotics, doctoral student,maarja.ojamaa@ut.ee 